Article

\title{
Physical Changes during Post-Mortem Ageing of High-Value Impala (Aepyceros Melampus) Steaks
}

\author{
Tersia Needham ${ }^{1,2}$, Retha A. Engels ${ }^{2}$ and Louwrens C. Hoffman ${ }^{2,3, *}$ (1) \\ 1 Department of Animal Science and Food Processing, Faculty of Tropical AgriSciences, Czech University of \\ Life Sciences Prague, Kamýcká 129, 16500 Prague-Suchdol, Czech Republic; needham@ftz.czu.cz \\ 2 Department of Animal Sciences, University of Stellenbosch, Private Bag X1, Matieland, \\ Stellenbosch 7602, South Africa; retha.engels@meadownatal.co.za \\ 3 Center for Nutrition and Food Sciences, Queensland Alliance for Agriculture and Food Innovation (QAAFI), \\ The University of Queensland, Health and Food Sciences Precinct, 39 Kessels Rd, Coopers, \\ Plains 4108, Australia \\ * Correspondence: louwrens.hoffman@uq.edu.au; Tel.: +61-4-1798-4547
}

Received: 1 June 2020; Accepted: 26 June 2020; Published: 29 June 2020

Featured Application: When harvested under minimal stress, prime impala steaks should be wet-aged in vacuum packaging under refrigerated conditions for eight days to ensure maximum tenderness, uniformity, and quality.

\begin{abstract}
Antelope meat production is rapidly growing, not only due to their adaptation to marginal land usage, but also because of its favorable nutritional properties and free-range production. However, limited information is available on the meat quality and processing potential of game meat for commercial consumption. The objective of this study was to determine the ageing period to achieve maximum tenderness of longissimus thoracis et lumborum (LTL) muscles of impala. The LTL muscles of 11 male and 11 female impala were harvested, and divided into eight portions. Each portion was randomly allocated to $1,2,4,6,8,10,12$, or 14 days of wet-ageing $\left(4^{\circ} \mathrm{C}\right)$ in vacuum packaging. The meat $\mathrm{pH}$, color, weep loss, cooking loss, and Warner-Bratzler shear force were measured throughout ageing. Initially the ageing profile differed depending on the sex of the animal from which the muscle was harvested; however, after 8 days of ageing, maximum tenderness was reached $(13.5 \pm 0.91 \mathrm{~N})$ and no further sex differences were seen. Ageing improved the surface color of all meat until day 8 , after which discoloration occurred. Therefore, it is recommended that impala LTL steaks should be wet-aged at $4{ }^{\circ} \mathrm{C}$ for eight days to achieve maximum tenderness and minimize sex variability.
\end{abstract}

Keywords: game meat; longissimus thoracis et lumborum; meat processing; tenderness; wet-ageing

\section{Introduction}

The current expansion of the human population is increasing the global demand for meat [1]; however, increasing meat production faces a number of challenges, including limited land availability, livestock feed supply, and climate change. Thus, domesticated livestock species alone may not be capable of meeting the expanding demand for animal protein, and therefore additional underutilized sources should be investigated [2,3]. While beef cattle are particularly vulnerable to desertification and bush encroachment brought on by climate change [4], antelope, in comparison, are well adapted to arid African environments, as they may utilize low-quality vegetation and are less susceptible to overgrazing [5]. Therefore, African antelope species represent a practical solution to increasing lean meat production, with promising results already reported for species such as the common eland 
(Taurotragus oryx) [6-9]. With the expansion of the South African game industry and the intensification of production systems for controlled breeding, more animals are available to be culled for meat production [10]. The meat of impala antelope (Aepyceros melampus) produces high carcass yields and dressing percentages, with meat that is high in protein and low in intramuscular fat [11], which makes it an attractive alternative protein source to traditional livestock for meat production [12,13]. However, game meat is considered as tough and dry by consumers, due to low product uniformity in commercially available game meat, as well as a lack of quality standards and knowledge on the proper cooking methods for game meat [14].

However, perceived meat quality is influenced by an array of ante and post-mortem factors, including species, age, sex, environmental and dietary factors, slaughtering conditions, and post-mortem processing of the meat [15]. Sex had minor influences on the meat production potential and physiochemical meat quality parameters of impala [11], but to develop the consumer market for game meat, supply chains must be capable of supplying products with consistently high-quality standards [16], in addition to improving consumer perception concerning the toughness of game meat. It is therefore necessary to investigate methods that may improve the texture and quality of meat from game species, of which wet-ageing has shown potential in other antelope species $[8,9,17]$. Post-mortem ageing not only improves the tenderness of meat through changes in the micro- and ultrastructure of muscle fibers [18], but it also influences other meat quality attributes such as juiciness, aroma, and flavor $[19,20]$. Currently, wet-ageing is favored commercially [21], whereby meat is vacuum packaged and stored under refrigerated conditions. The reason for this being that moisture loss and shrinkage during ageing is decreased, and wet-ageing provides a higher convenience during transport and storage of the meat [22,23].

While the fresh meat quality of impala indicates that their meat may be considered as tender after $24 \mathrm{~h}$ post-mortem [11], ageing may not only further benefit tenderness, but also the sensory eating quality and transportation of meat from isolated production areas to commercial sale points. However, the influence of post-mortem ageing on the meat quality of impala has not yet been investigated. Thus, the aim of this study was to determine the optimum post-mortem ageing period, based primarily on tenderness and color, of the longissimus thoracis et lumborum (LTL) muscle of impala meat from both sexes.

\section{Materials and Methods}

\subsection{Experimental Design, Animals, and Sample Collection}

Twenty-two subadult (15-18 months old; 11 males and 11 females) impala were culled (ethical approval number 10NP_HOF02) using light caliber rifles (.22 or .243) fitted with a suppressor. The impala were kept within a 200 ha semiextensive production system at a stocking density of 250-300 animals, within the Savanna biome of Modimolle (Limpopo, South Africa). The natural vegetation [24] formed the primary feed source, and a supplementary feed was provided daily according to the recommended dietary requirements for this species [25]. Feed samples were taken throughout the study and pooled before analysis according to the Association of Official Analytical Chemists International (AOAC 934.01, 992.15, 942.05, 962.0) [26] for moisture (8.3\%), crude protein $(91.7 \%)$, ash $(27.9 \%)$, and fiber components (crude fiber: $27.9 \%$, neutral detergent fiber: $47.7 \%$ and acid detergent fiber $30.5 \%)$.

Immediately after being shot, each impala was exsanguinated and transported to the slaughter facilities on-farm, where they were eviscerated and processed according to standard guidelines [27]. Dressed carcasses were then hung in a chiller set to $4 \pm 1^{\circ} \mathrm{C}$ to undergo rigor mortis. After $24 \mathrm{~h}$, all impala carcasses were deboned, and the left longissimus thoracis et lumborum (LTL) muscles were excised. Each LTL muscle was divided into eight equal steaks with a thickness of approximately two centimeters each, cut at a right angle to the longitudinal axis of the muscle. Each steak was randomly allocated to one of the following ageing days: $1,2,4,6,8,10,12$, and 14 . The samples 
allocated to Day 1 (D1) were analyzed on the day of deboning (24 h post-mortem), whereas each steak allocated to the remaining days was weighed, vacuum sealed in composite plastic bags $(70 \mu \mathrm{m}$ nylon and polyethylene; oxygen permeability of $30 \mathrm{~cm}^{3} / \mathrm{m}^{2} /$ day/atm, carbon dioxide permeability of $105 \mathrm{~cm}^{3} / \mathrm{m}^{2} /$ day/atm and moisture vapor transfer rate of $2.2 \mathrm{~g} / \mathrm{m}^{2} /$ day/atm) with a $5 \mathrm{mb}$ residual pressure (Multivac, Model C200, Sepp Haggenmuller, Wolfertschwenden, Germany) and stored in a chiller at $4 \pm 1{ }^{\circ} \mathrm{C}$ until the allocated day of physical analysis.

\subsection{Physical Meat Quality Evaluation throughout Ageing}

At each of the aforementioned time points, the relevant steaks were assessed for physical meat quality parameters. Firstly, moisture loss was determined by removing the steak, blotting it dry, and then weighing it to determine the weep loss, as a percentage of the steak's original weight. Thereafter, the $\mathrm{pH}$ was measured with a two-point calibrated (using standard buffers of $\mathrm{pH} 4$ and $\mathrm{pH}$ 7) Crison $\mathrm{pH} 25$ portable $\mathrm{pH}$ meter (Crison instruments, Barcelona, Spain) with a glass electrode. Measurements were taken by inserting the electrode at an angle as close to the center of each steak as possible. Between each measurement, the electrode was cleaned by rinsing with distilled water and blotted dry with absorbent paper. The steaks were then allowed to bloom for $30 \mathrm{~min}$, after which color measurements were taken with a calibrated Color-guide $45^{\circ} / 0^{\circ}$ colorimeter $(4 \mathrm{~mm}$ aperture, $2^{\circ}$ observer angle; BYK-Gardner $\mathrm{GmbH}$, Gerestried, Germany) at five random positions, and averaged per sample. The International Commission on Illumination (CIE) system was used, where hue angle (color definition) and chroma values (saturation/color intensity) were calculated from $L^{*}$ (lightness), $a^{*}$ (red-green spectrum) and $b^{*}$ (blue-yellow spectrum) values according to the following equations:

$$
\begin{aligned}
& \text { Hue angle }\left({ }^{\circ}\right)=\tan ^{-1}\left(\frac{b^{*}}{a^{*}}\right) \\
& \text { Chroma }(C *)=\sqrt{\left(a^{* 2}+b^{* 2}\right)}
\end{aligned}
$$

Subsequently, the cooking loss of each sample was determined by placing a weighed piece of steak inside a thin plastic bag and cooking in a preheated water bath $\left(80^{\circ} \mathrm{C}\right)$ for a period of $60 \mathrm{~min}$ [6]. All steaks from the relevant ageing day were cooked in one batch and each steak was fully submerged for the duration of the cooking period. After $60 \mathrm{~min}$, the cooked steaks were removed from the water bath and excess water was drained before chilling at $4 \pm 1{ }^{\circ} \mathrm{C}$ for approximately six hours until cooled. Thereafter, the steaks were blotted dry with absorbent paper and weighed, and moisture loss was expressed as a percentage of the initial weight of the uncooked steak [28].

Following the cooking loss determination, the Warner-Bratzler shear force (WBSF) was measured using six cylindrical core samples (diameter: $1.27 \mathrm{~cm}$ ) taken from the center of each steak, while excluding visible connective tissue. The cores were placed within the Warner-Bratzler blade such that they were cut at a right angle to the longitudinal axis of the fibers (blade speed: $3.33 \mathrm{~mm} / \mathrm{s}$ ) and the peak force during cutting was recorded in Newtons $(\mathrm{N})$. The mean force was determined from the six samples per steak, with lower shear force values indicating higher tenderness.

\subsection{Statistical Analysis}

The experimental design was a randomized block split plot, with the animal as the block, sex as the main plot factor and ageing period (days post-mortem) as the split plot factor. Both main effects (sex and ageing period) were tested, as well as their interaction. The parameters of the physical analysis $(\mathrm{pH}$, weep loss, cooking loss, Warner-Bratzler shear force, and color) were analyzed using general linear models to establish univariate ANOVAs (analysis of variance) in SAS (Version 9.4; SAS Institute Inc., Cary, USA). Normality of the data was ensured using Shapiro-Wilk tests. No outlier values were seen within the data. Fisher's least significant difference post hoc testing was used to compare sex, muscle, and ageing period means. A significance level of $5 \%$ was considered throughout. 


\section{Results}

Main effects are summarized in Table 1; however, significant interactions were observed between sex and ageing period for $\mathrm{pH}(p=0.028)$, cooking loss percentage $(p=0.020)$, Warner-Bratzler shear force $(p<0.001)$, CIE $L^{*}$ value $(p=0.004)$, CIE $a^{*}$ value $(p=0.001)$, and chroma value $(p=0.001)$ of impala meat. Thus, these interactions and not their main effects will be discussed. No interactions were recorded between sex and ageing period for weep loss percentage, CIE $b^{*}$ value, or the hue angle of impala meat (Table 1).

Sex did not have an influence on the weep loss percentage of impala meat (Table 1). However, weep loss was influenced $(\mathrm{p}<0.001)$ by the ageing period, with the lowest weep loss percentage recorded on day $2(3.7 \pm 0.27 \%)$. Thereafter, weep loss percentage increased until day $6(5.9 \pm 0.28 \%)$, after which a plateau was reached until the end of the ageing period on day $14(6.4 \pm 0.27 \%)$.

Male impala meat had a significantly higher $\mathrm{pH}(p=0.028)$ than female impala meat on days 2 , $4,6,10$, and 14, with the highest $\mathrm{pH}$ recorded for male impala meat on day $14(5.9 \pm 0.03)$ (Figure 1$)$. However, no significant differences between sexes were recorded for days 1, 8, or $12 \mathrm{for} \mathrm{pH}$.

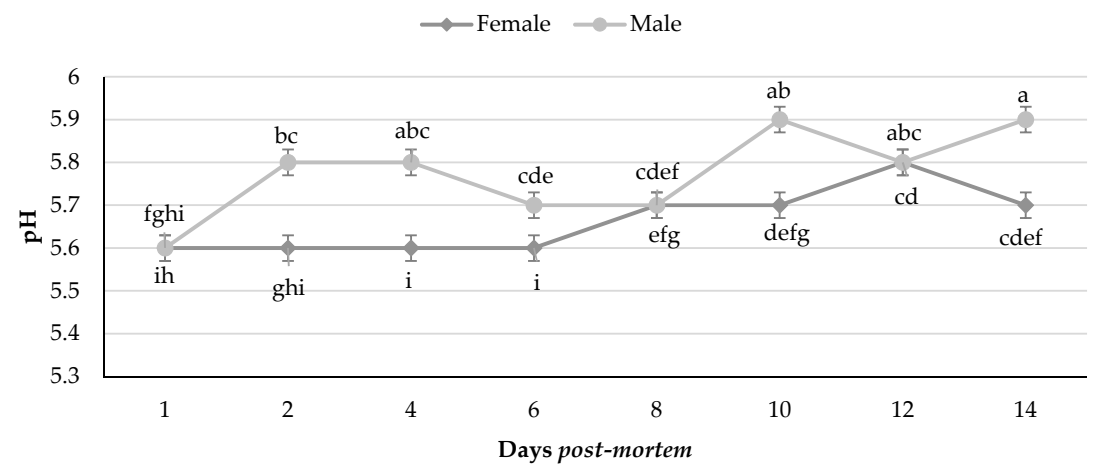

Figure 1. Effect of sex and ageing (days post-mortem) on the $\mathrm{pH}$ of female and male impala longissimus thoracis et lumborum muscles. ${ }^{\mathrm{a}-\mathrm{i}}$ Means with different superscripts differ from one another $(p \leq 0.05)$. Error bars represent the standard error of the means.

Female impala meat was found to have significantly higher cooking loss percentages than that of males on 1,2, 4, 8, and 14 days post-mortem ( $p=0.020$; Figure 2 ). The highest cooking loss percentage $(33.3 \pm 0.46 \%)$ was recorded on day 4 for female impala meat and the lowest cooking loss percentage $(29.5 \pm 0.46 \%)$ was recorded on day 1 for male impala meat. No differences were recorded between the sexes for days 6,10 , and 12. A general trend can be observed with female impala meat having slightly higher overall LTL muscle cooking loss percentages than males for the duration of the ageing period.

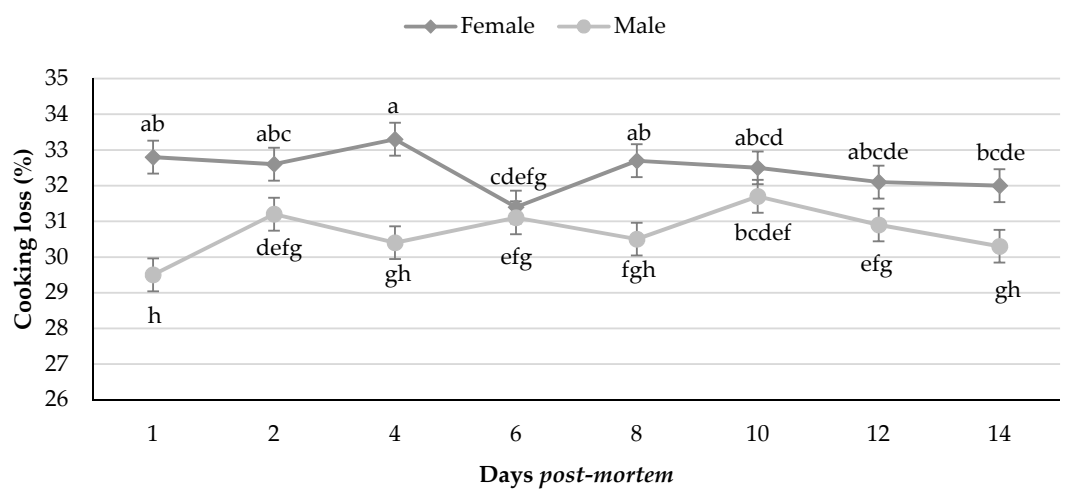

Figure 2. Effect of sex and ageing (days post-mortem) on the cooking loss percentage of female and male impala longissimus thoracis et lumborum muscles. ${ }^{\mathrm{a}-\mathrm{h}}$ Means with different superscripts differ from one another $(p \leq 0.05)$. Error bars represent the standard error of the means. 
Table 1. Effect of sex and ageing period (days post-mortem) on the physical parameters of impala longissimus thoracis et lumborum meat. Significant interactions were found for $\mathrm{pH}$, cooking loss, shear force, $\mathrm{L}^{*}, \mathrm{a}^{*}$, and chroma values, and thus main effects are not interpreted but depicted within the table only.

\begin{tabular}{|c|c|c|c|c|c|c|c|c|c|c|c|c|c|c|c|}
\hline \multirow{2}{*}{ Parameter } & \multicolumn{4}{|c|}{ Sex } & \multicolumn{10}{|c|}{ Days Post-Mortem } & \multirow{2}{*}{ Sex $\times$ Days Post-Mortem $r$} \\
\hline & Female & Male & SEM & $p$ & 1 & 2 & 4 & 6 & 8 & 10 & 12 & 14 & SEM & $p$ & \\
\hline $\mathrm{pH}$ & 5.6 & 5.8 & 0.04 & 0.050 & $5.6^{\mathrm{c}}$ & $5.7^{b}$ & $5.7^{b}$ & $5.7 \mathrm{bc}$ & $5.7^{b}$ & $5.8^{\mathrm{a}}$ & $5.8^{\mathrm{a}}$ & $5.8^{\mathrm{a}}$ & 0.02 & $<0.001$ & 0.028 \\
\hline Weep loss (\%) & 6.0 & 5.5 & 0.46 & 0.427 & * & $3.7^{c}$ & $4.7^{\mathrm{b}}$ & $5.9^{\mathrm{a}}$ & $6.4^{\mathrm{a}}$ & $6.5^{\mathrm{a}}$ & $6.5^{\mathrm{a}}$ & $6.4^{\mathrm{a}}$ & 0.27 & $<0.001$ & 0.468 \\
\hline Cooking loss (\%) & 32.4 & 30.7 & 0.54 & 0.034 & $31.1^{\mathrm{b}}$ & $31.9^{\mathrm{ab}}$ & $31.8^{\mathrm{ab}}$ & $31.2 \mathrm{ab}$ & $31.6^{\mathrm{ab}}$ & $32.1^{\mathrm{a}}$ & $31.5^{\mathrm{ab}}$ & $31.1^{\mathrm{b}}$ & 0.33 & 0.222 & 0.020 \\
\hline Shear force $(\mathrm{N})$ & 18.3 & 14.9 & 1.00 & 0.026 & $25.5^{\mathrm{a}}$ & $21.9^{\mathrm{b}}$ & $20.5^{\mathrm{b}}$ & $16.9^{\mathrm{c}}$ & $13.5^{\mathrm{d}}$ & $12.2^{\mathrm{ed}}$ & $11.3^{\text {ed }}$ & $10.8^{\mathrm{e}}$ & 0.91 & $<0.001$ & $<0.001$ \\
\hline $\mathrm{L}^{*}$ & 33.6 & 33.0 & 1.11 & 0.692 & $31.8^{\mathrm{c}}$ & $33.8^{\mathrm{ab}}$ & $33.2^{\mathrm{ab}}$ & $33.0^{\mathrm{b}}$ & $33.2^{\mathrm{ab}}$ & $34.0^{\mathrm{a}}$ & $33.9^{a b}$ & $33.4 \mathrm{ab}$ & 0.32 & $<0.001$ & 0.004 \\
\hline$a^{*}$ & 12.7 & 12.7 & 0.46 & 0.945 & $12.5^{\mathrm{bc}}$ & $11.3^{\mathrm{d}}$ & $12.4^{\mathrm{c}}$ & $13.4^{\mathrm{a}}$ & $13.1^{\mathrm{a}}$ & $13.1^{\mathrm{a}}$ & $12.9^{\mathrm{ab}}$ & $13.0^{\mathrm{ab}}$ & 0.18 & $<0.001$ & 0.001 \\
\hline $\mathbf{b}^{*}$ & 8.9 & 8.3 & 0.77 & 0.557 & $7.6^{\mathrm{d}}$ & $7.9^{\mathrm{cd}}$ & $8.4^{\mathrm{bc}}$ & $8.7^{a b}$ & $8.8^{\mathrm{ab}}$ & $9.2^{\mathrm{a}}$ & $9.1^{\mathrm{a}}$ & $9.3^{\mathrm{a}}$ & 0.23 & $<0.001$ & 0.201 \\
\hline Chroma & 15.7 & 15.3 & 0.80 & 0.010 & $14.8^{\mathrm{b}}$ & $13.9^{c}$ & $15.1^{\mathrm{b}}$ & $16.1^{\mathrm{a}}$ & $15.9^{a}$ & $16.1^{\mathrm{a}}$ & $15.9^{a}$ & $16.1^{\mathrm{a}}$ & 0.22 & $<0.001$ & 0.001 \\
\hline Hue angle & 36.5 & 32.8 & 1.81 & 0.384 & $30.5^{c}$ & $34.5^{\mathrm{a}}$ & $33.4^{\mathrm{ab}}$ & $32.2 \mathrm{bc}$ & $33.2^{\mathrm{ab}}$ & $34.5^{\mathrm{a}}$ & $34.6^{\mathrm{a}}$ & $34.7^{\mathrm{a}}$ & 0.73 & $<0.001$ & 0.481 \\
\hline
\end{tabular}

Abbreviations: SEM: standard error of the mean, $\mathrm{L}^{*}$ : lightness from 0 (black) to 100 (white), $\mathrm{a}^{*}$ : lightness from red (-) to green $(+)$ spectrum, $\mathrm{b}^{*}$ : lightness from blue (-) to yellow (+) spectrum. *No weep loss was measured on day one as physical analysis occurred prior to packaging. ${ }^{-e}$ Means with different letters within each main effect differ from each other $(p \leq 0.05$ ). 
Female impala meat had higher $(p=0.004) L^{*}$ values than male impala on day 8 and day 10 of ageing. There were no significant differences between sexes for the remaining six time points (Figure 3). Female impala also had higher $(p=0.001) a^{*}$ values on day $4(13.0 \pm 0.26)$ than male impala $(11.8 \pm 0.26)$, whereas males had higher $(p \leq 0.05) a^{*}$ values on day $12(13.4 \pm 0.26)$ than females $(12.5 \pm 0.26)$ (Figure 4). No significant differences between sexes were recorded for days 1, 2, 6, 8, 10, or 14 .

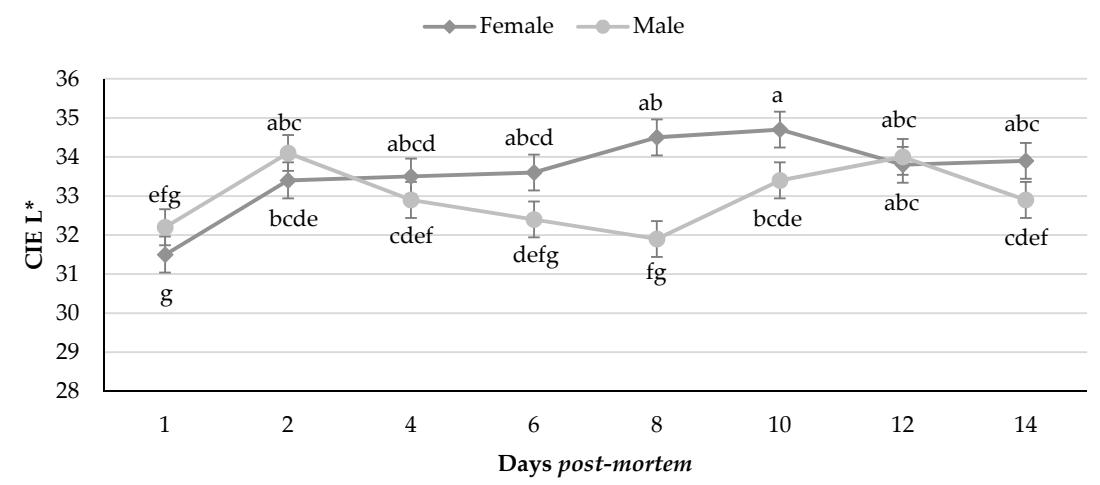

Figure 3. Effect of sex and ageing (days post-mortem) on the $L^{*}$ (lightness) values of the surface color of impala longissimus thoracis et lumborum meat from females and males. ${ }^{\mathrm{a}-\mathrm{g}}$ Means with different superscripts differ from one another $(p \leq 0.05)$. Error bars represent the standard error of the means.

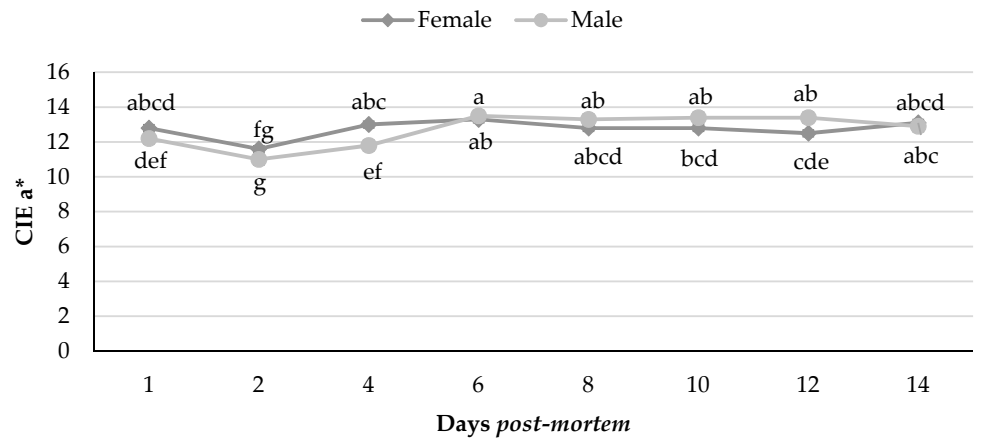

Figure 4. Effect of sex and ageing (days post-mortem) on the $a^{*}$ values (red-green spectrum) of the surface color of impala longissimus thoracis et lumborum meat from females and males. ${ }^{a-g}$ Means with different superscripts differ from one another $(p \leq 0.05)$. Error bars represent the standard error of the means.

The interaction $(p<0.001)$ between sex and ageing period for the chroma values of impala meat is presented in Figure 5. Female impala had higher chroma values than males on day 1, 2, 4, and 14 post-mortem, while males had higher chroma values than female impala on day 12 .

No interactions were recorded between sex and ageing period for the $b^{*}$ values or hue angles of impala LTL muscles, and there were no differences between sexes (Table 1). However, the post-mortem ageing period had a significant influence on the $b^{*}$ values of impala LTL meat. The lowest $b^{*}$ values were recorded on day $1(7.6 \pm 0.23)$, with a steady increase as the ageing period progressed until a plateau was reached at the highest $b^{*}$ values from day 10 onwards (Table 1 ). The post-mortem ageing period also had an influence $(p<0.001)$ on the hue angle, which was lowest on day 1 , after which it fluctuated between day 2 to 8 , where after it reached a plateau from day 10 until day 14 .

Female impala meat had higher $(p<0.001)$ shear force values than males at day 1,2 , and 4 , while no differences were recorded between the sexes from day 6 to day 14 (Figure 6). All muscles, regardless of sex, showed a gradual decline in shear force values until day 8 , after which a plateau was reached until the end of the ageing period at day 14. 


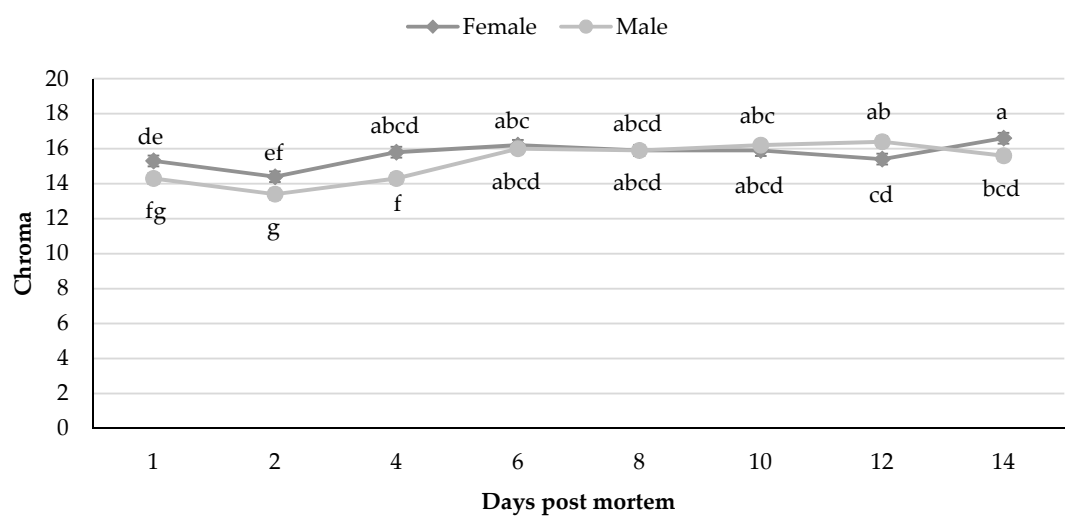

Figure 5. Effect of sex and ageing (days post-mortem) on the chroma values of the surface color of impala longissimus thoracis et lumborum meat from females and males. ${ }^{\mathrm{a}-\mathrm{g}}$ Means with different superscripts differ from one another $(p \leq 0.05)$. Error bars represent the standard error of the means.

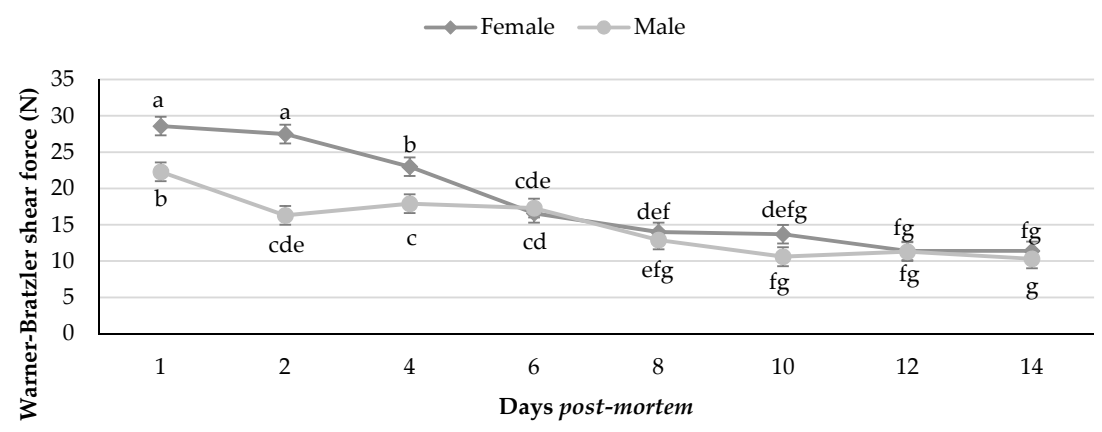

Figure 6. Effect of sex and ageing (days post-mortem) on the Warner-Bratzler shear force (N) of female and male impala longissimus thoracis et lumborum muscles. ${ }^{\mathrm{a}-\mathrm{h}}$ Means with different superscripts differ from one another $(p \leq 0.05)$. Error bars represent the standard error of the means.

\section{Discussion}

Despite the slight fluctuations in meat $\mathrm{pH}$ throughout the ageing period, a general increase in $\mathrm{pH}$ can be observed over ageing period. A similar overall increase in $\mathrm{pH}$ occurred in eland LTL steaks from day 2 to day 21 [8] and for springbok from day 1 until day 5 [17]. Boakye and Mittal [29] also recorded an overall $\mathrm{pH}$ increase in vacuum-aged beef until day 16 post-mortem, and attributed this increase to fluctuations in the charge of meat proteins as a consequence of proteolytic enzyme activity.

Whilst post-mortem ageing was shown to improve meat tenderness, ageing is often accompanied by weep loss, an unfavorable effect caused by moisture lost from raw meat which is considered unattractive to consumers [30]. Weep loss is affected by changes in the muscle $\mathrm{pH}$ post-mortem, as well as the rate and extent of proteolysis and protein oxidation, as the degradation of cytoskeletal proteins results in shrinkage of the muscle cells and the reduction of their ability to retain water [30]. In the present study, the changes in the weep loss percentage of impala LTL steaks were as expected, with a plateau being reached on day 6 post-mortem. This plateau in weep loss percentage as the ageing period progresses is similar to observations in previous studies in game [8,17], and is the consequence of a limited amount of unbound water in the meat for exudation. For vacuum-aged meat, a weep loss of one to two percent is considered acceptable by consumers, while more than four percent may be considered excessive [31]. Whilst the weep loss for impala meat over the ageing period exceeded this at every time point, other factors such as compression during vacuum packaging can influence this significantly [32], with up to $13 \%$ of the moisture lost being accountable to losses from vacuum sealing [8]. Nonetheless, the weep loss from impala steaks in the current study were comparable to that of springbok during ageing [17], which is of similar body size and muscle yield to impala, but the 
use of absorbent pads to minimize the visual appearance of the weep could be considered for wet-aged cuts from these species sold in vacuum packaging.

The surface color of meat is an important quality attribute that influences the consumer acceptability at the point of purchase, as color is often equated to meat "freshness" [33,34]. Discoloration in meat is thus a primary cause of lost retail sales which force producers to discard or devalue substantial amounts of retailed meat [35]. Discoloration can occur on the surface of meat due to oxidative processes resulting in increased metmyoglobin formation and thus a brown surface color that is considered unacceptable by consumers [36]. Therefore, it is important to monitor the color stability of meat throughout the post-mortem ageing process, to ensure that discoloration does not occur and that a consistent, high-quality and valuable game meat product remains [37]. The color parameters for the impala LTL steaks in the present study indicates that the surface color becomes lighter, redder and more saturated as the ageing period progresses. However, the $\mathrm{a}^{*}$ values of the aged impala LTL steaks remained well above the established minimum of 12 for consumer acceptability [38] from 6-14 days post-mortem. A significant increase was observed for both the $b^{*}$ and hue angle values of the aged impala LTL steaks from day 1 until day 8, after which a plateau was reached from day 10 onwards. The increase in hue angle shows that the impala LTL steaks in the present study became duller and browner after 10 days of ageing, with this discoloration potentially indicating microbial spoilage [39]. Thus, it is recommended that impala steaks should not be aged more than 8 days post-mortem to prevent discoloration.

The cooking loss of LTL steaks from female impala was at a maximum of 3.3\% higher than that of males on some ageing days in the present study, which is likely due to the changes in $\mathrm{pH}$, but did not have a significant influence on the shear force of the meat. Tenderness and its variability are the most important sensory meat quality characteristics for consumers influencing the repurchase of such products [15]. The variability in tenderness is largely influenced by differences in its structural components. The concentration of the collagen, and the extent of collagen cross-linking, determines the baseline toughness of the meat, the latter of which can only be altered to a limited extent $[40,41]$. Meat tenderness is therefore primarily improved by means of post-mortem proteolysis of the structural proteins within muscle fibers during ageing [41]. The shear force (tenderness) of the impala meat in the present study was improved by ageing, where the largest influence of sex was seen between days 1 to 4 post-mortem. This result may be due to the female impala in the present study being older (estimated at 24 to 36 months old) than the male impala ( $\pm 15-18$ months old) as a result of difficulty estimating the age of female impala in the field, as they have no horns. Nonetheless, after 6 days of ageing, the variation in shear force values between the sexes was negated. Overall, post-mortem ageing decreased the shear force values of impala LTL steaks from $25.5 \pm 0.91 \mathrm{~N}$ on day 1 to $13.5 \pm 0.91 \mathrm{~N}$ on day 8 , where after no further benefit was seen for tenderness or color. A similar decrease in shear force $(13.8 \mathrm{~N})$ was observed from springbok under similar ageing conditions, after five days of ageing [17]. However, in beef, up to 14 days of ageing is required to realize this decrease in shear force (10-16 N) [42,43]. The ultimate or maximum tenderness of meat is determined by the rate and extent that myofibrillar proteins are degraded during post-mortem proteolysis [18], and is recorded to be higher in certain game species than beef due to increased activity of proteolytic enzyme [44].

\section{Conclusions}

Wet-ageing decreased the variability of shear force values in impala meat from different sexes after eight days post-mortem, thereby improving product uniformity and its marketability. Ageing further than this provided no further benefit in tenderness, and resulted in discoloration. It is recommended that sensory evaluation be performed to determine whether aroma, flavor, and texture attributes are altered by this ageing period, to ensure optimal consumer acceptability.

Author Contributions: Conceptualization, methodology, funding acquisition, and supervision, L.C.H.; investigation, data collection, and project execution, R.A.E.; data interpretation, original draft preparation, 
and editing, T.N.; review and editing, L.C.H. and R.A.E. All authors have read and agree to the published version of the manuscript.

Funding: This research is supported by the South African Research Chairs Initiative (SARChI) and partly funded by the South African Department of Science and Technology (UID number: 84633), as administered by the National Research Foundation (NRF) of South Africa, and partly by the Department of Trade and Industry's THRIP program (THRIP/64/19/04/2017) with Wildlife Ranching South Africa as partner and by Stellenbosch University. Any opinions, findings and conclusions or recommendations expressed in this material are that of the author(s) and the National Research Foundation does not accept any liability in this regard.

Acknowledgments: The authors would like to acknowledge the Internal Grant Agency (IGA) FTZ CZU, Prague (no. IGA20205005) for their support. The authors would also like to thank Castle de Wildt (South Africa, http://www.castledewildt.co.za/wildlife-breeding/) for the donation of the animals.

Conflicts of Interest: The authors declare no conflict of interest.

\section{References}

1. Meissner, H.H.; Scholtz, M.M.; Palmer, A.R. Sustainability of the South African livestock sector towards 2050 Part 1: Worth and impact of the sector. S. Afr. J. Anim. Sci. 2013, 43, 282-297. [CrossRef]

2. Cawthorn, D.M.; Hoffman, L.C. The role of traditional and non-traditional meat animals in feeding a growing and evolving world. Anim. Front. 2014, 4, 6-12. [CrossRef]

3. Conceicao, P.; Fuentes-Nieva, R.; Horn-Phathanothai, L.; Ngororano, A. Food security and human development in Africa: Strategic considerations and directions for further research. Afr. Dev. Rev. 2011, 23, 237-246. [CrossRef]

4. Otieno, J.; Muchapondwa, E. Agriculture and Adaptation to Climate Change: The Role of Wildlife Ranching in South Africa, Economic Research South Africa, Working Paper no 579. Available online: https://www.econrsa.org/system/files/publications/working_papers/working_paper_579.pdf (accessed on 27 May 2020).

5. Oberem, P.; Oberem, P. The New Game Rancher; Briza Publications: Pretoria, South Africa, 2016.

6. Needham, T.; Bureš, D.; Kotrba, R.; Hoffman, L.C. Influence of sex on the muscle yield and physiochemical characteristics of fresh meat harvested from common eland (Taurotragus oryx). Meat Sci. 2019, 152, 41-48. [CrossRef] [PubMed]

7. Needham, T.; Laubser, J.G.; Kotrba, R.; Bureš, D.; Smyth, H.; Hoffman, L.C. Sensory characteristics of the longissimus thoracis et lumborum and biceps femoris muscles from male and female common eland (Taurotragus oryx). Meat Sci. 2019, 158, 107918. [CrossRef]

8. Needham, T.; Laubser, J.G.; Kotrba, R.; Bureš, D.; Hoffman, L.C. Influence of ageing on the physical qualities of the longissimus thoracis et lumborum and biceps femoris muscles from male and female free-ranging common eland (Taurotragus oryx). Meat Sci. 2019, 159, 107922. [CrossRef]

9. Needham, T.; Kotrba, R.; Hoffman, L.C.; Bureš, D. Ante- and post-mortem strategies to improve the meat quality of high-value muscles harvested from farmed male common eland (Taurotragus oryx). Meat Sci. 2020, 168, 108183. [CrossRef]

10. Bothma, J.; Du, P.; Sartorius Von Bach, H.J.; Cloete, P.C. Economics of the wildlife industry in South Africa. In Game Ranch Management, 6th ed.; Bothma, J.D., P. Du Toit, J.G., Eds.; Van Schaik Publishers: Pretoria, South Africa, 2016; pp. 85-94.

11. Needham, T.; Engels, R.A.; Bureš, D.; Kotrba, R.; Van Rensburg, B.J.; Hoffman, L.C. Carcass Yields and Physiochemical Meat Quality of Semi-extensive and Intensively Farmed Impala (Aepyceros melampus). Foods 2020, 9, 418. [CrossRef]

12. Hoffman, L.C. The yield and carcass chemical composition of impala (Aepyceros melampus), a southern African antelope species. J. Sci. Food Agric. 2000, 80, 752-756. [CrossRef]

13. Hoffman, L.C.; Wiklund, E. Game and venison-Meat for the modern consumer. Meat Sci. 2016, 74, 197-208. [CrossRef]

14. Radder, L.; Le Roux, R. Factors affecting food choice in relation to venison: A South African example. Meat Sci. 2005, 71, 583-589. [CrossRef] [PubMed]

15. Listrat, A.; Lebret, B.; Louveau, I.; Astruc, T.; Bonnet, M.; Lefaucheur, L.; Picard, B.; Bugeon, J. How muscle structure and composition influence meat and flesh quality. Sci. World J. 2016, 2016, 3182746. [CrossRef] [PubMed] 
16. Hutchison, C.L.; Mulley, R.C.; Wiklund, E.; Flesch, J.S. Consumer evaluation of venison sensory quality: Effects of sex, body condition score and carcase suspension method. Meat Sci. 2010, 86, 311-316. [CrossRef] [PubMed]

17. North, M.K.; Frylinck, L.; Hoffman, L.C. The physical and biochemical changes in springbok (Antidorcas marsupialis) Longissimus thoracis et lumborum and Biceps femoris muscle during ageing. Meat Sci. 2015, 110, 145-152. [CrossRef] [PubMed]

18. Nowak, D. Enzymes in tenderization of meat-The system of calpains and other systems-A review. Pol. J. Food Nutr. Sci. 2011, 61, 231-237. [CrossRef]

19. Monsón, F.; Sañudo, C.; Sierra, I. Influence of breed and ageing time on the sensory meat quality and consumer acceptability in intensively reared beef. Meat Sci. 2015, 71, 471-479. [CrossRef]

20. Sitz, B.M.; Calkins, C.R.; Feuz, D.M.; Umberger, W.J.; Eskridge, K.M. Consumer sensory acceptance and value of wet-aged and dry-aged beef steaks. J. Anim. Sci. 2016, 84, 1221-1226. [CrossRef]

21. Smith, R.D.; Nicholson, K.L.; Nicholson, J.D.W.; Harris, K.B.; Miller, R.K.; Griffin, D.B.; Savell, J.W. Dry versus wet aging of beef: Retail cutting yields and consumer palatability evaluations of steaks from US Choice and US Select short loins. Meat Sci. 2008, 79, 631-639. [CrossRef]

22. Hodges, J.H.; Cahill, V.R.; Ockerman, H.W. Effect of vacuum packaging on weight loss, microbial growth and palatability of fresh beef wholesale cuts. J. Food Sci. 1974, 39, 143-146. [CrossRef]

23. Warren, K.E.; Kastner, C.L. A comparison of dry-aged and vacuum-aged beef strip loins. J. Muscle Foods 1992, 3, 151-157. [CrossRef]

24. Mucina, L.; Rutherford, M.C. The Vegetation of South Africa, Lesotho and Swaziland; South African National Biodiversity Institute: Pretoria, South Africa, 2006.

25. Furstenburg, D. Impala (Aepyceros melampus). In The New Game Rancher; Oberem, P., Oberem, P., Eds.; Briza Publications: Pretoria, South Africa, 2016; pp. 217-225.

26. Association of Official Analytical Chemist International. Official Method of Analysis, 17th ed.; Association of Official Analytical Chemists Inc.: Arlington, TX, USA, 2002.

27. Van Schalkwyk, D.L.; Hoffman, L.C. Guidelines for the Harvesting and Processing of Wild Game in Namibia 2016; Ministry of Environment \& Tourism: Windhoek, Namibia, 2016.

28. Honikel, K.O. Reference methods for the assessment of physical characteristics of meat. Meat Sci. 1998, 49, 447-457. [CrossRef]

29. Boakye, K.; Mittal, G.S. Changes in $\mathrm{pH}$ and water holding properties of Longissimus dorsi muscle during beef ageing. Meat Sci. 1993, 34, 335-349. [CrossRef]

30. Huff-Lonergan, E.; Lonergan, S.M. Mechanisms of water-holding capacity of meat: The role of post-mortem biochemical and structural changes. Meat Sci. 2005, 71, 194-204. [CrossRef] [PubMed]

31. Colle, M.J.; Richard, R.P.; Killinger, K.M.; Bohlscheid, J.C.; Gray, A.R.; Loucks, W.I.; Day, R.N.; Cochran, A.S.; Nasados, J.A.; Doumit, M.E. Influence of extended aging on beef quality characteristics and sensory perception of steaks from the biceps femoris and semimembranosus. Meat Sci. 2016, 110, 32-39. [CrossRef]

32. Payne, S.R.; Durham, C.J.; Scott, S.M.; Devine, C.E. The effects of non-vacuum packaging systems on drip loss from chilled beef. Meat Sci. 1998, 49, 277-287. [CrossRef]

33. Mancini, R.A.; Hunt, M.C. Current research in meat color. Meat Sci. 2005, 71, 100-121. [CrossRef]

34. Troy, D.J.; Kerry, J.P. Consumer perception and the role of science in the meat industry. Meat Sci. 2010, 86, 214-226. [CrossRef]

35. McKenna, D.R.; Mies, P.D.; Baird, B.E.; Pfeiffer, K.D.; Ellebracht, J.W.; Savell, J.W. Biochemical and physical factors affecting discoloration characteristics of 19 bovine muscles. Meat Sci. 2005, 70, 665-682. [CrossRef]

36. Neethling, N.E.; Suman, S.P.; Sigge, G.O.; Hoffman, L.C. Muscle-specific colour stability of blesbok (Damaliscus pygargus phillipsi) meat. Meat Sci. 2016, 119, 69-79. [CrossRef]

37. Neethling, N.E.; Suman, S.P.; Sigge, G.O.; Hoffman, L.C.; Hunt, M.C. Exogenous and endogenous factors influencing color of fresh meat from ungulates. Meat Muscle Biol. 2017, 1, 253-275. [CrossRef]

38. Wiklund, E.; Stevenson-Barry, J.M.; Duncan, S.J.; Littlejohn, R.P. Electrical stimulation of red deer (Cervus elaphus) carcasses-Effects on rate of $\mathrm{pH}$-decline, meat tenderness, colour stability and water-holding capacity. Meat Sci. 2001, 59, 211-220. [CrossRef]

39. Shange, N.; Gouws, P.; Homan, L.C. Changes in $\mathrm{pH}$, color and the microbiology of black wildebeest (Connochaetes gnou) longissimus thoracis et lumborum (LTL) muscle with normal and high (DFD) muscle pH. Meat Sci. 2019, 147, 13-19. [CrossRef] [PubMed] 
40. Purslow, P.P. Intramuscular connective tissue and its role in meat quality. Meat Sci. 2005, 70, 435-447. [CrossRef] [PubMed]

41. Sentandreu, M.A.; Coulis, G.; Ouali, A. Role of muscle endopeptidases and their inhibitors in meat tenderness. Trends Food Sci. Technol. 2002, 13, 400-421. [CrossRef]

42. Crouse, J.D.; Koohmaraie, M. Effect of freezing of beef on subsequent post-mortem aging and shear force. J. Food Sci. 1990, 55, 573-574. [CrossRef]

43. Shackelford, S.D.; Wheeler, T.L.; Koohmaraie, M. Tenderness classification of beef: I. Evaluation of beef longissimus shear force at 1 or 2 days post-mortem as a predictor of aged beef tenderness. J. Anim. Sci. 1997, 75, 2417-2422. [CrossRef]

44. Barnier, V.M.; Wiklund, E.; Van Dijk, A.; Smulders, F.J.M.; Malmfors, G. Proteolytic enzyme and inhibitor levels in reindeer (Rangifer tarandus tarandus $L$ ) vs. bovine longissimus muscle, as they relate to ageing rate and response. Rangifer 1999, 19, 13-18. [CrossRef]

(C) 2020 by the authors. Licensee MDPI, Basel, Switzerland. This article is an open access article distributed under the terms and conditions of the Creative Commons Attribution (CC BY) license (http://creativecommons.org/licenses/by/4.0/). 